\title{
RESEARCH PROJECTS TO STUDY THE SEA FLOOR AND SUB-BOTTOM SEDIMENTS FUNDED BY THE RECENT EUROPEAN COMMISSION FRAMEWORK PROGRAMS: THE I.G.M.E. PARTICIPATION
}

\author{
Perissoratis C. and Ioakim Chr. \\ Institute of Geology and Mineral Exploration, Athens, C'Entrance, Olympic Village, \\ Acharnae, Athens, 13677 Greece
}

\begin{abstract}
Since 1983, after the participation of Greece in the European Union (EU), IGME has carried out many research projects relevant to earth sciences funded by the European Commission (EC). Especially in the sector of Marine Sciences, a number of projects have been funded in cooperation with other European Institutes. The main targets of the research projects were relevant to the tasks described in the various framework programs (FP) evaluated by the EC, with the tasks changing according to the decision of the European Parliament. The marine projects became gradually larger in terms of the number of the participating Institutes while their target focused more toward to the society needs such as the sustainable energy resources and environmental problems. In this presentation we will describe the research projects relevant to the above targets that were carried out in the last 10 years partly or entirely in the Greek seas.
\end{abstract}

Key words: Hyace, Anaximander, Hermes, Hermione, European Projects.

\section{Introduction}

\subsection{EC Priorities and relevant Projects}

Description of priorities

The priorities of the projects that will be described are related in general to the research on the Gas Hydrates $(\mathrm{GH})$ present in the sea sub bottom and to environmental problems affecting the marine realm. GH were targets in the projects HYACE and ANAXIMANDER, and the environment by the projects HERMES and HERMIONE.

$\mathrm{GH}$ are ice crystals composed of 6 to $8 \mathrm{H}_{2} \mathrm{O}$ locking a molecule of hydrocarbon in solid forms, usually methane. They are present in sedimentary layers and were first observed at the beginning of the $20^{\text {th }}$ century during oil drillings in ice land areas,. During the 1970's they were firstly reported within the sub bottom layers in the deep seas due to a sudden increase in the sound velocity, that was diminished in the underlying layers. During the following decades an impressive quantity of $\mathrm{GH}$ was found on or below the oceanic sea bottom. Today it is estimated up to over $90 \%$ of GH in the earth is present at the deep ocean sub-bottom sedimentary layers (Fig. 1).

This caused the interest of many countries (such as USA, EU, Japan, India, China, S. Corea) considering $\mathrm{GH}$ as a possible sea floor energy source, but also as a possible impact in the sea floor insta- 


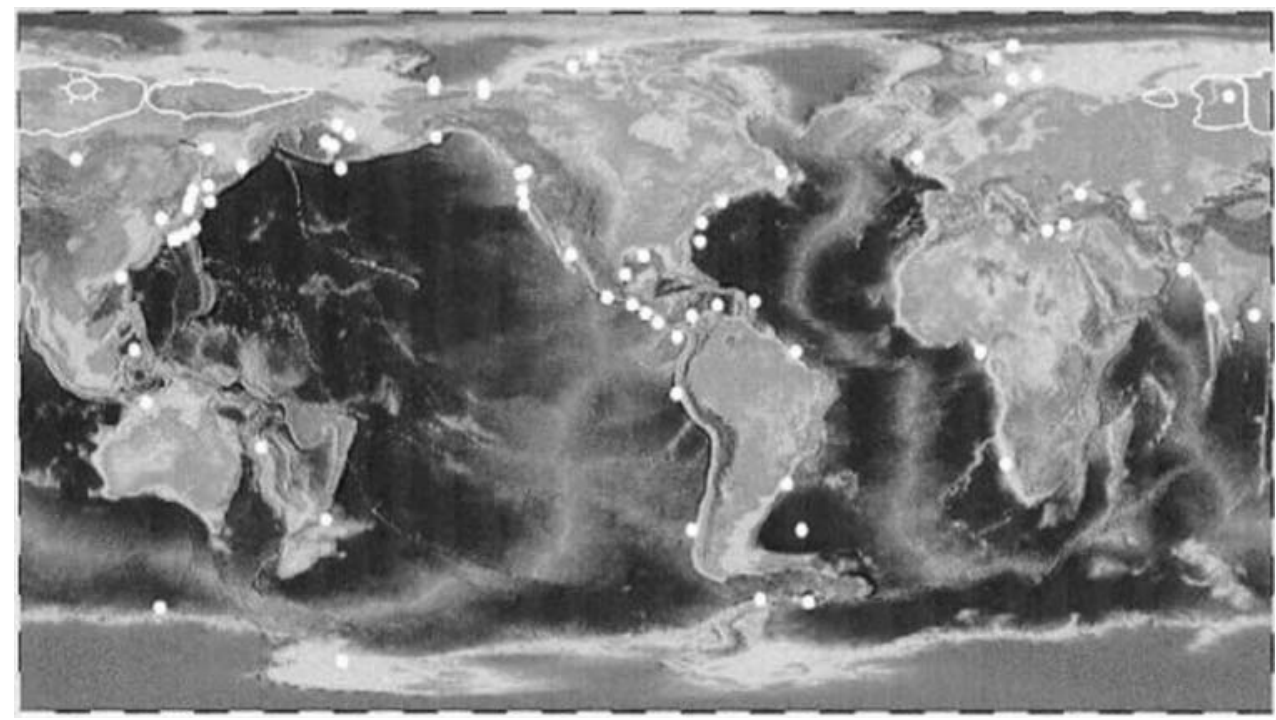

Fig. 1: The worldwide presence of Gas Hydrates.

bility caused by an eventual future GH dissociation and release of the methane. For example many large sediment slides on the continental slopes were understood in the context of the gas hydrates. This is because if only part of the gas will be released due to a sediment failure and be entrapped might result in a climate change. Apart of these the recent estimations indicate that the total of carbon in the GH world wide is in the volume of about $500 \mathrm{Gt}$ that is about $5 \%$ of the carbon present in the earth (Milkov, A.V. 2000; Fig. 2). With this estimated amount, the globally available carbon in GH is high, taking into account the fact that conventional fossil fuels are getting more and more exploited.

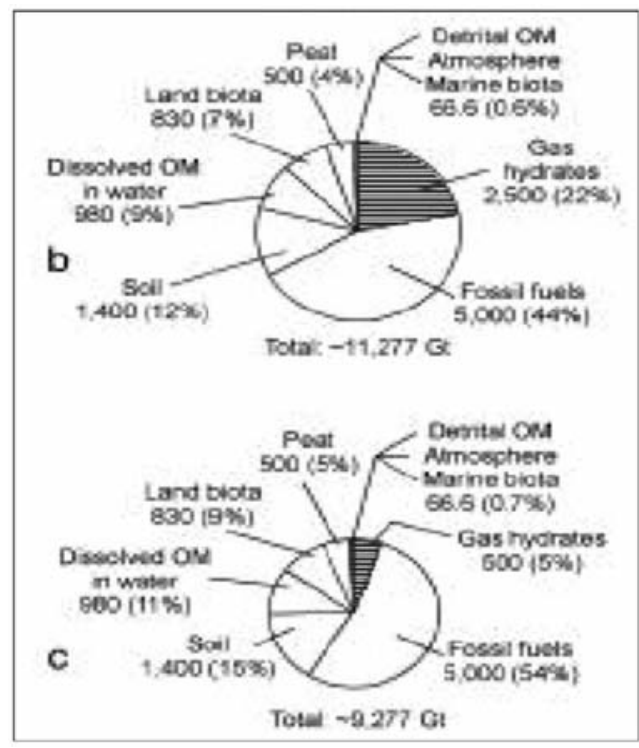

Fig. 2: Schematic representation of the organic worldwide presence of Gas Hydrates (in Gt) by Milkov 2000. 
The study though of the unique environment of the GH presents a number of considerable difficulties related to their remote location, the great sea depth, the need of new tools for in situ sampling and sample conservation and integrity, the examination of their characteristics and properties and the release of the entrapped methane. As it turned out thou from recent marine $\mathrm{GH}$ research, mainly from exploration but also from exploitation studies, the marine GH occurrences are lacking substantial reservoir characteristics to warrant economic exploitation. This scepticism, already expressed some years ago, has not yet been overcome. Another main problem also originates from the non-existence of a cap rock package on top of the GH containing sediments.

In respect the environmental issues, the study of problems on biodiversity, structure, function and dynamics of ecosystems along Europe's deep-ocean margin has been gradually becoming a main task for a comprehensive European Ocean and Seas Integrated Governance Policy. Actually it represents now the first major attempt to understand European deep-water ecosystems and their natural environment in an integrated way (geosphere, hydrosphere, biosphere in pan-European range). This must be carried out in the European margin from Norway to the Black Sea, instead of studying just one area in one region alone. Thus the targets have been to compare and contrast a suite of key environments around which, by virtue of their geographic locations, to experience quite different environmental settings. Important targets were the extensive study of the dynamic structures, of all shelf, slope and rise of the European seas. These researches required urgent study because of their possible biological fragility, global relevance to carbon cycling and/or susceptibility to catastrophic events and to global change. The participating members, Institutes and private companies were urged to cover as many as possible European countries, within and beyond the EU.

\section{Description of projects}

\subsection{Project HYACE}

The project was named HYACE for "Hydrate Autoclave Coring Equipment" and was carried out from 1997 to 2000. It had as target the construction of a corer that could be lowered within the seafloor drilling tubes, in GH containing layers, collect GH and keep them in situ conditions for laboratory studies (Amann 1998, 2000, Perissoratis et al., 1998).

The corer was designed to sample marine sediments in a down hole conditions and bring it on board while maintaining as many down hole parameters as possible. Particular targets were sediments on the deepwater covered continental slopes containing GH. The main general goal of the project was to contribute to the systematic ground trotting of sampling and analysis of GH in their natural environment. In parallel a main target was also to obtain the information on GH and the detailed knowledge of their geology and to predict the changes on pressure and /or temperature during their dehydration processes.

The plan included formation of a corer with three sampling tools, a push, a rotary and a percussion tool to be used depending to the characteristics and the hardness of the sediments to be sampled. Positive areas where these corers can be used included the North Atlantic, the Eastern and Northwestern Pacific Ocean, and other European seas. For this purpose marine geological field work was carried in 1999 south of Peloponnesus, where study of previous seismic profiling data showed possible presence of $\mathrm{GH}$, but the researches showed that the sub-bottom horizons did not contained GH. In spite of the fact that in $1996 \mathrm{GH}$ were already discovered and collected in the Anaximander seamountains in the Eastern Mediterranean. Nevertheless The HYACE corers were successfully used during drilling ODP project Leg 194 in the Pacific Ocean (Fig. 3, 4). 


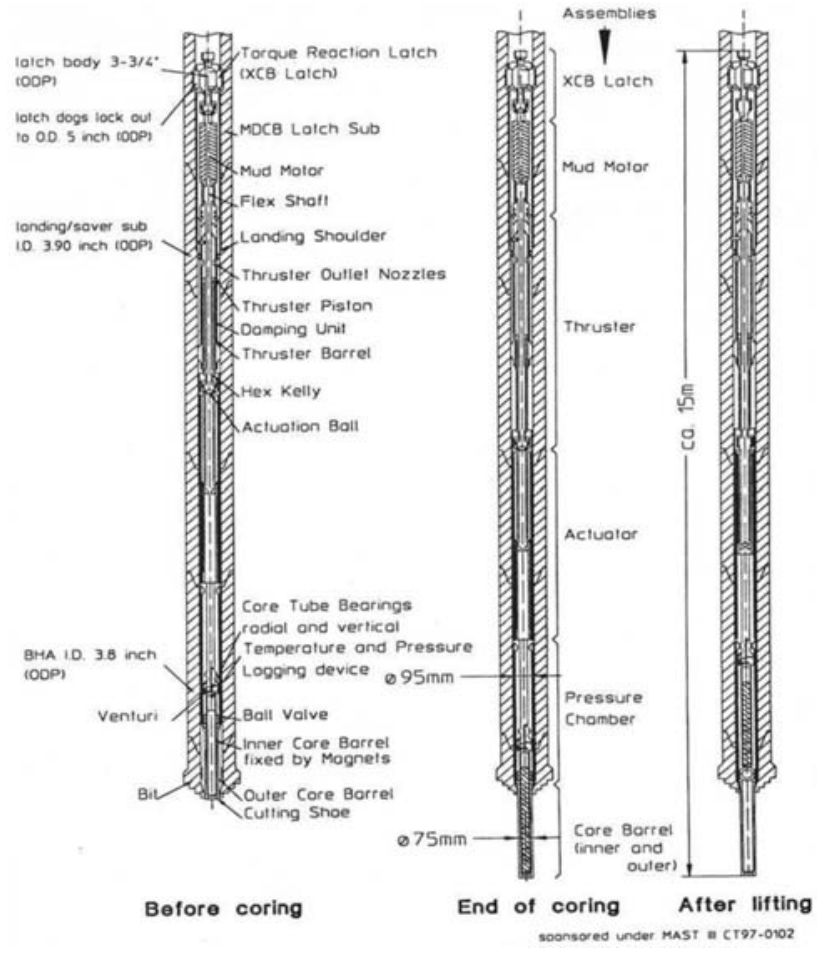

Fig. 3: The Autoclave core sponsored under MAST III.
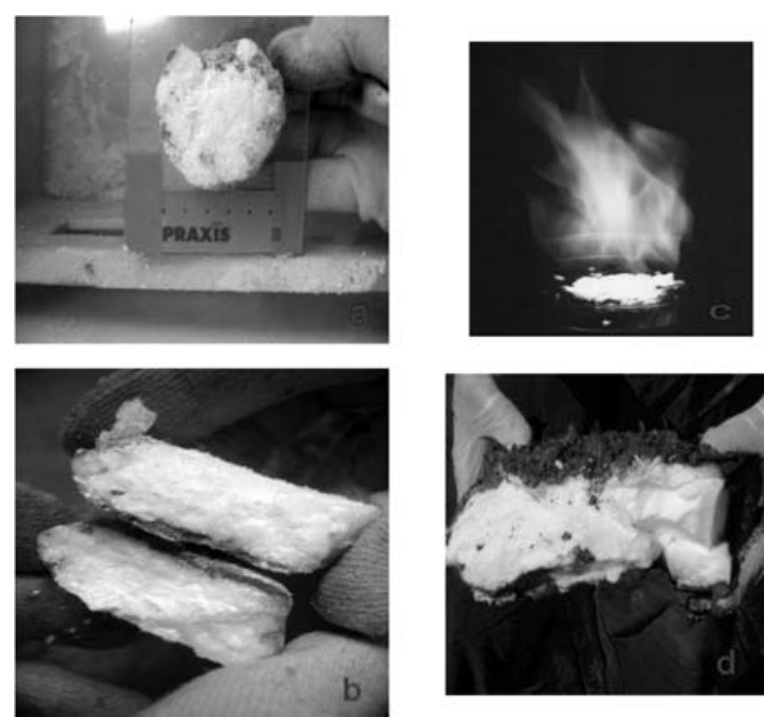

Fig. 4: Gas Hydrates crystals collected during the Anaximander cruises (a, b). Gas Hydrates from the Pacific Ocean /GEOMAR cruise (c, d).

In the HYACE project participated, exept IGME, Institutes from Germany, France, Spain, The Netherlands, and The United Kingdom, Coordination was the Technical University of Berlin. 


\subsection{Project ANAXIMANDER}

Based on the discovering of GH in the Eastern Mediterranean during general marine researches in the Mediterranean from 1996 to 1999 (Woodside et al., 1996,1999), by Dutch and Russian research ships a project was proposed at the Anaximander Mountains (Mts) and funded by the EC in 2002. The project named ANAXIMANDER "Exploration and Evaluation of the Eastern Mediterannean Sea Gas Hydrates and the associated deep biosphere" was carried out from 2002 to 2006 during which two 15 days field works were carried out in 2003 and 2004 respectively. According to the previous experience in HYACE and other researches, an integrated approach was needed for a successful consideration of the above diverse and difficult challenges and the research team constituted to undertake this task (Fig. 5) because the selected area for conducting the GH study, has a quite deep average sea bottom depth, over $2000 \mathrm{~m}$ and bottom temperature $12-14^{\circ} \mathrm{C}$. In addition to the presence of $\mathrm{GH}$ a characteristic unique and rich biota was observed along with occurrence of abundant methane. Thus the research team of ANAXIMANDER (Perissoratis et al. 2004) had to proceed beyond the current knowledge by using appropriate and innovative coring and sampling instruments to obtain and bring on board undisturbed "pristine" cores. The purpose was to carry out sub-sampling with minimum distortion on the various GH containing sediment properties and keep the associated bio-communities unaffected. Also applied a methodological experimental innovation in order to analyze and then synthesize the laboratory results of the GH containing sediments, their dissociation kinetics processes, and the associated deep biosphere. At the same time and during this research previously unknown potential GH occurrences were continuously discovered within the EU economic zone (offshore Eastern Spain, offshore Portugal, Black Sea, Northern Atlantic, North Sea), and this caused the outcome of the ANAXIMANDER project particularly important.

The research was carried out by using a deep low sidescan sonar and sub-bottom profiling. The data indicated that there are areas where there is a high gas content in the sediment and possibly seeps. Initially the three principal targets for sampling of GH in the Anaximander Mountains region were the Amsterdam, Kula, and Kazan Mud Volcanoes (MVs) where GH were sampled during the earlier cruises by. During the project discovered two new, previously unknown, MVs that were named Athina and Thessaloniki MVs. The first research however was carried out (May 2003) the Amsterdam MV because it appeared to have the larger central area where GH could be sampled, as Amsterdam MV was considered the most active of the MVs in the area. At previous targets, also Kula MV was sampled. Then during the second cruise (November 2004) the MVs Kazan, Athina and Thessaloniki were studied. All these targets were within the GH stability zone; thus it was assumed that these areas constitute areas of GH presence as long as there is a sufficient source of GH presence. The continuing preliminary examination of the existing data in the Anaximander Mountains region confirmed the initial choices of sites and indicated the whole area as a potential GH occurrence. All these sites span a considerable range of water depths, from $2236 \mathrm{~m}$, slope of Amsterdam MV, to $1263 \mathrm{~m}$ at the summit of Thessaloniki MV, the latter depth coincides with the upper boundary of the hydrate stability zone (Lykousis et al., 2004, a,b; Perissoratis et al., 2006, 2007). Also the mud breccia recovered from all mud volcanoes (Amsterdam, Kazan, Kula, Athina and Thessaloniki) contained numerous rock clasts from the deep seated strata of Mts.

The researches undertaken by IGME were the depositional processes, the GH presence, the mud volcanic activity and the geological evolution of the Anaximander area.

The mud volcanoes in the Anaximander Mts erupted a poorly sorted matrix-supported breccia, con- 


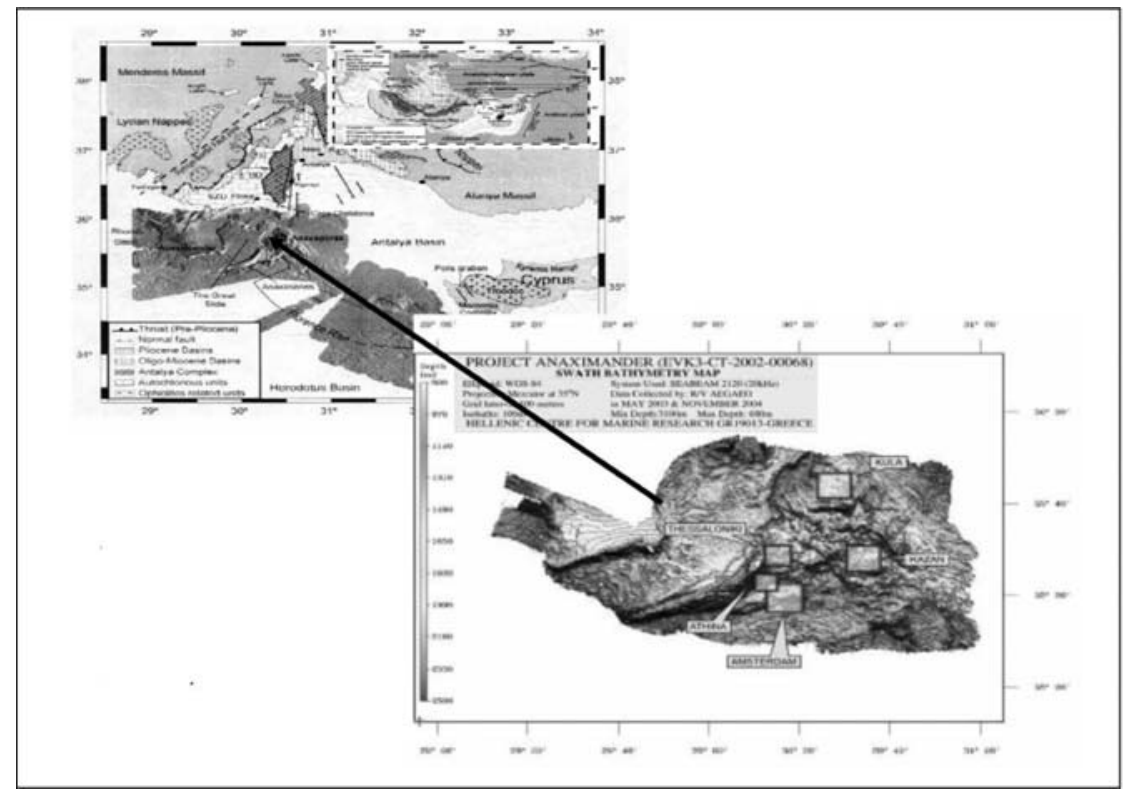

Fig. 5: The detailed bathymetric map of the Anaximander Mountains (Anaximander project) and its adjacents areas (by Ten Veen et al. 2004).

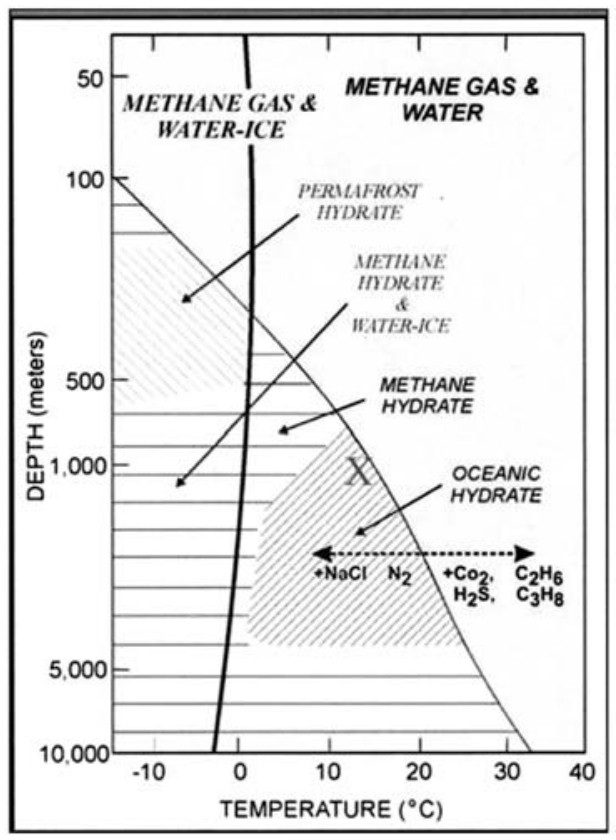

Fig. 6: Schematic representation of Gas Hydrates Stability Zone (GHSZ) -X the case of Thessaloniki Mud Volcano.

taining rock clasts derived from lower lying formations. Thus, the morphology, petrography and biostratigraphy of the mud breccia clasts from Amsterdam, Kazan, Kula, Athina and Thessaloniki MVs (Fig. 4) helped us in outlying the deep stratigraphy and hence to obtain a better understanding 

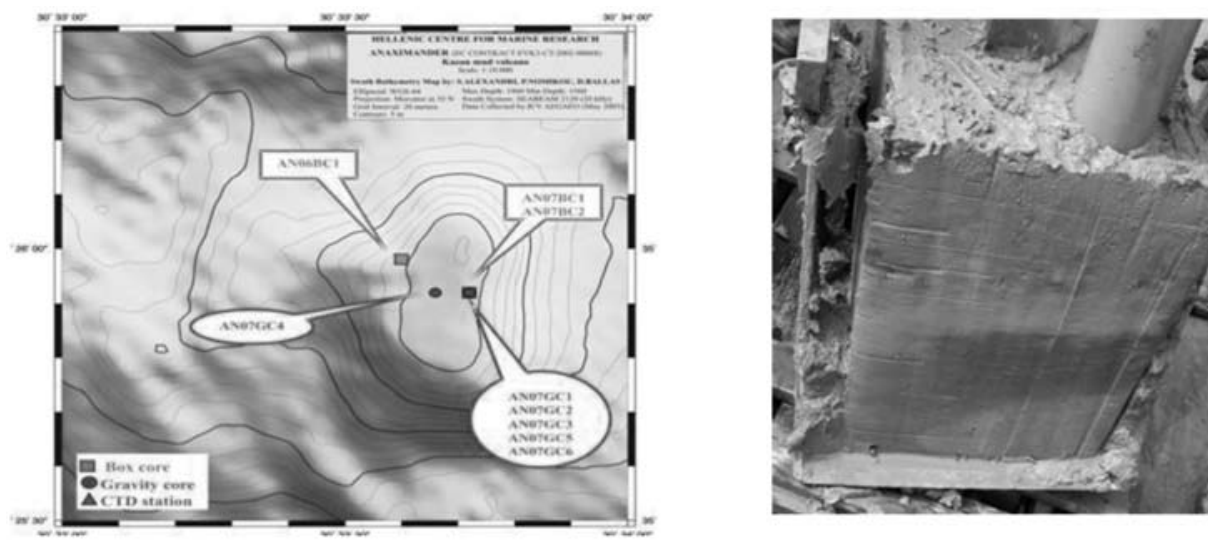

Fig. 7: Lithological sequence of AN06BC1 box core and the bathymetric map of Kazan Mud Volcano (courtesy D. Sakellariou and S. Alexandri).

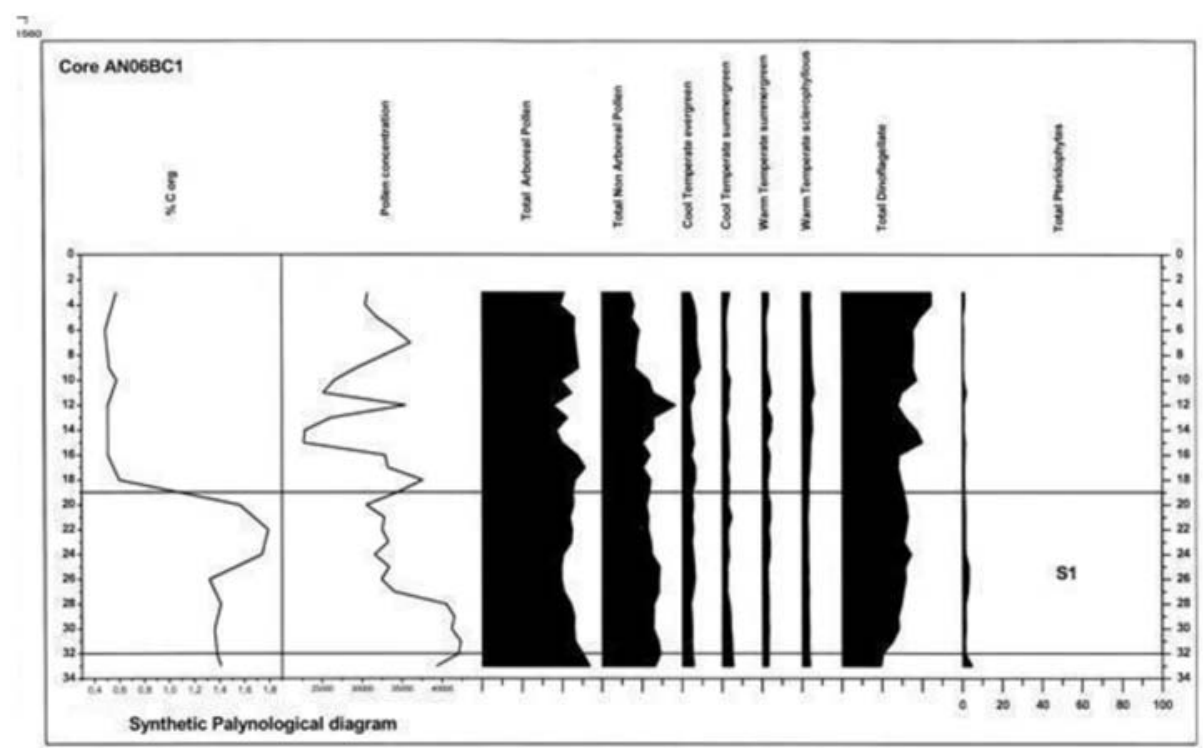

Fig. 8: Synthetic representation of selected palynomorph fossils included in the pelagic sediments.

of the formation and geological evolution of the Anaximander mud volcanoes. Also microfacies analyses (foraminifera) and petrography carried out on thin sections through microscope and X-ray diffraction (XRD) analyses provided a more precise estimation of the relative age of the source rock formations and a subsequent determination of the depositional environment during the rock formation (Ioakim et al., 2004, 2005; Casas et.al., 2006). The Eastern Mediterranean is characterized by repeated stagnant anoxic episodes (Figs 7,8) and volcanic eruptions that resulted in the deposition of sapropels and ash layers that in turn permitted the correlation from core to core. According to the obtained data (C14 measurements, the tephra and isotopic chronology) and the presence of the Sapropel S1 led to interpret a volcanic reactivation about 10 kyrs approximately (Ioakim, et al., 2004, 2005; Lykousis et al., 2005; Vougioukalakis, et al., 2005). 
In respect to the $\mathrm{GH}$ presence the data do not permit an unequivocal decision as to the base of the GH stability zone (GHSZ) and we had to rely on the thermodynamic data in order to assess its depth and, eventually estimate the volume of GH present. According to these data the calculated depth of the base of the GHSZ (Fig. 5, 6), ranges between 125 and $240 \mathrm{~m}$. We assumed a depth of $150 \mathrm{~m}$ and calculated the volume of sediment containing GH in the Eastern Mediterranean to $22.5 \mathrm{~km}^{3}$. Considering the percentage of GH in the sediment about 10\%, the volume of GH in the Anaximander area was estimated at $0.25 \mathrm{~km}^{3}$.

In the Anaximander project the eight participants were from research Institutes from Greece (IGME coordinator, HCMR), Germany, The Netherlands and Spain.

\subsection{Project HERMES}

The HERMES project stands for "Hotspot Ecosystem Research on the Margins of the European Seas" and provided new research into the study of the European sea bottom all around the European seas. The project had to answer how the various human activities in combination with the expected climatic changes will affect the sea environment in Europe. It started in 2005 and ended in 2009.

The project targets were the following: How human activities interfere with ecosystems? How vulnerable are ecosystems to man's intrusions? How quickly are they able to recover? Can we mitigate the negative environmental impacts of man's activities and reach a sustainable balance? Can EU realize its commitment to sustainable development and international treaties ? And finally what is the likely effect of global change on an ecosystems stability. Thus to answer these questions HERMES focuses particularly to ecosystem "hotspots" that are strongly physically mediated hydrogeological structures, including: unstable slope systems, canyons, deep-water coral habitats, cold seeps, gas and associated with dynamic geological and/or hydrates, mud volcanoes and anoxic microbial systems. These important systems required study because of their possible biological fragility, global relevance to carbon cycling and/or susceptibility to catastrophic events and to global change.

For IGME parts of the targets of HERMES project was a follow up work of the Anaximander project and were related in obtaining more knowledge on two main subjects: First the specific role and characteristics of the Gas Hydrates $(\mathrm{GH})$ in terms of a possible impacts to the climate in case of their dissociation and a methodology for its possible use as an energy source. Second to study the climatic changes mainly in the last 32.000 years BP up to now, documented on micropalaeontological data and isotopic analysis obtained from the sediment analyses in two long gravity cores collected from greater area of Amsterdam MV and in the offshore area south of Crete. During the Hermes project were also examined further the interpretations of the palaeoenvironmental conditions and the link of the geological processes with the presence or absence of Gas Hydrates (Ioakim et al., 2004, 2005; Perissoratis, et al., 2007). In addition, the geological relation was examined existing between the sub bottom sedimentary horizons and the rock formations outlying at the sea sub-bottom with the sedimentary horizons present in the adjacent land of the Greek islands and at South Turkey.

For the possible environment impact of the released methane presented in the area, two scenarios were considered. First continuous methane release, with slow release rate and microbial mediated oxidation in the sediment or in the water column with no methane entering to the atmosphere. Second instantaneous release of free gas (out burst event) rapid released rate, no reaction in the sediment nor in the water column, absence of biologically mediated nor organic oxidation of methane and immediate release into the atmosphere. 
With the data at hand and taking into account the great depth of GH field in the area (from $2500 \mathrm{~m}$ to $1260 \mathrm{~m}$ ) it was conclude that in both scenarios the possibility of a geological hazard to occur and affect the nearby land (great slide, explosive event, tsunamis) is low to negligible even by assuming a $10 \mathrm{~m}$ sea level lowering and $1{ }^{\circ} \mathrm{C}$ decrease in temperature and an increase in salinity. As for the possibility of the use of methane present in the $\mathrm{GH}$ as an energy source, the data indicated that the quantity of methane is insufficient, and the hydrate density within the sediment is rather low. In addition the event of methane production is today cost preventing due to the great sea water depths, the remote location and the absence of offshore infrastructure. However more in depth researches are needed to fully evaluate the occurrence of GH and the total amount of GH at the Eastern Mediterranean area.

For the Palaeoclimatic - Palaeoceanographic conditions, the data showed that the sediments center of MVs constituted by mud breccia and in many cases included gas hydrates. In the sediments around the MVs there were hemipelagic sediments that contained the sapropelic layers S1 and S2 as well as the volcanic ash layer Y2 (Ioakim, et al., 2005; Vougioukalakis et al., 2004). The dating of all these horizons provided the palaeogeographic and palaeoceanographic reconstructions of the area and indicated that there is a specific correlation between the north Eastern Mediterranean sub bottom stratigraphy and the statigraphy of the Alpine Belt that outcrops at the adjacent land northwards (Eastern Greek islands, Southern Turkey). The volcanic ash layer Y2 was related to the Cape Riva eruption of Santorini (around $21 \mathrm{Kyrs}$ ago). According to the obtained data (C14 measurements, the tephra and isotopic chronology) and the presence of the Sapropel S1 it is concluded that the volcanic reactivation takes place in a period of about $10 \mathrm{kyrs}$.

In the HERMES project participated over 50 Scientific Centers and Universities from almost all European countries. Local Coordinator in Greece was HCMR.

\subsection{Project HERMIONE}

The Hermione project (Hotspot Ecosystem Research and Man's Impact on European Seas) is again a follow up of the ended Hermes project, started in 2009, has three years duration and plans to investigate ecosystems at critical sites on Europe. These are the deep ocean margin, including Mediterranean, Northeast Atlantic, and part of the Antarctic Ocean. It has as target to clarify specific adaptations of deep sea organisms inhabiting seamounts and the adjacent deep-sea basins in relation to their ecology. It will also provide new insights into the importance of the different structural and functional attributes of biodiversity in functioning of seamounts ecosystems.

\section{Conclusions}

The results in each of the projects were briefly by the present authors are described in the previous sections and of course represent team work not only of the authors but of all participants. However the important general outcome of these EC funded scientific researches is that this cooperation is presents the opportunities to work with the best research centers in Europe. At the same time provides the necessary funding for both carrying out the research in our areas and update the laboratory and field instruments. The continuous participation in meetings and seminars, the presentations of the preliminary and final results, the submission of the necessary final reports in time in proper way and form, and finally but not les important, the evaluation by international experts of the final reports, both in their scientific and economic aspects are very important. As a result of the above, a large number of papers by the working groups is published in volumes of international meetings and journals. 


\section{Acknowledgments}

We greatly acknowledge the European Commission for funding the projects HYACE (MAS3-CT970102), ANAXIMANDER (EVK-CT-2002-00068) and HERMES (GOCE-CT-2005-511234-1). For the carrying out of all these projects we greatly acknowledge and thank all cooperating scientists, both in Geek and European Institutes and Universities throughout the work in all theses years, and especially the geologists and technicians in IGME and HCMR.

\section{References}

Amann, H., Baraza, J., Marx, C., Perissoratis, C., Roberts, J., Skinner, A., Valdy, P., and Zuidberg, H., 1998. HYACE, An Autoclave coring equipment for systematic offshore sampling, measurement and ground truthing. Third European MAST Conference, Lisbon, 23-27 May,1998, v. IV, p. 1531-1540.

Amann, H., Baraza, J., Marx, C., Perissoratis, C., Roberts, J., Skinner, A., Valdy, P., And Zuidberg, H., 1998. HYACE, Autoclave coring tools for systematic offshore sampling, measurement and ground truthing. EUROCEAN 2000, European Commission Hamburg, Aug.29-Sept. 2, Vol.1, p 670-673.

Casas D., Ercila G., Lykousis V., Ioakim Chr. and Perissoratis C., 2006. Physical properties and their relationship to sedimentary processes and texture in sediments from mud volcanoes in the Anaximander Mountains (Easter Mediterranean). Scientia Marina, Spain, 70/4, 643 - 650.

Ioakim, Chr., Perissoratis, C., Lykousis, V. \& Sakellariou, D. 2004. Palaeoclimatic-palaeooceanographic records of a long deep sea core from the Anaximander Mountains, Eastern Mediterranean. $11^{\text {th }}$ International Palynological Congress, Spain, July 4-9, 2004. Conf. Proceedings Vol. 14, p. 413-414.

Ioakim, Chr., Tsala-Monopolis, S., Dimou, E. Perissoratis, C., \& Lykousis, V. 2005. Age and sedimentary succession of rock clasts from Anaximander mud volcanoes bacteria, Eastern Mediterranean. $12^{\text {th }}$ Congress R.C.M.N.S., 6-11 September 2005, Vienna

Ioakim, Chr., Tsaila - Monopolis, St., Perissoratis, C., Lykousis, V., and the Anaximander Scientific party, 2005. The examination of the gas hydrates hosting environment at the Anaximander Mud Volcanoes, Eastern Mediterranean: Stratigraphy and Sedimentary successions at the mud breccia clasts, CIESM Workshop Monograph, v. 29, p. 87-96.

Lykousis V., Alexandi S. Woodside J. Lange G., de, Sakellariou D, Nomikou P., Ioakim Chr., Daelman, A., Casas, D., Roussakis, G., Ballas, D., Kormas K., Kioroglou S., \& Perissoratis C., 2004a. Mud volcanoes and related gas hydrates in Anaximander mountains (Eastern Mediterranean). New discoveries from the 01/May 03 cruise of RV Aegaeo (Anaximander project). $5^{\text {th }}$ Inter. Symposium on Eastern Mediterranean Geology, v. 3, 1353-1357.

Lykousis, V., Alexandri, S., Woodside, J., Nomikou, P., Perissoratis, C., Sakellariou, D., de Lange, G., Dahlmann, A., Casas, D., Rousakis, G., Ballas, D. \& Ioakim C., 2004b. New evidence of extensive active mud volcanism in the Anaximander mountains (Eastern Mediterranean): The "ATHINA" mud volcano. Environmental Geology, 46, 1030-1037.

Milkov, A, V. 2000. Worldwide distribution of submarine mud volcanoes and associated gas hydrates. Marine Geology, 167 (1-2): 29-42.

Perissoratis, C., Ioakim. Chr., Zacharaki, P., Lykousis, V., Sakellariou, D., Kormas, K., Woodside, J., Amann, H., Maggiulli, M., Daehlmamm, A., De Lange, G., Casas, D., Ercilla, G., Meyn, V., Varotsis, N., \& Marinakis, D. 2004. Exploration and Evaluation of the Eastern Mediterranean Gas Hydrates and the Associated Deep Biosphere - (ANAXIMANDER). EUROCEAN 2004 Conference, Galway, Ireland, May 10-13, 2004, Conf. Proc. p. 139-140.

Perissoratis, C., Ioakim, Chr., Lykousis, V., Alexandri, S., Nomikou, P., Woodside, J., Daehlmann, A., Heeschen, K., Casas D., and the Anaximander shipboard scientific parties, 2006. Characteristics of the Thessaloniki Mud Volcano, a recently discovered gas hydrate bearing area in the Anaximander Moun- 
tains, Eastern Mediterranean. Geophysical Research Abstracts, Vol. 8, 03874, SRef-ID: 16077962/gra/EGU06-A-03874.

Perissoratis C. Lykousis V., Ioakim Chr., 2007. The hydro-carbons, usually methane,locked in solid forms within the Gas Hydrates present in the Eastern Mediterranean sea floor:characteristics, formation and impacts. Geophysical Research Abstracts,Vol.9, 11715, 2007

Ten Veen J, Woodside J, Zitter T, Dumont J, Mascle J and Volkonskaia, A, (2004) Neotectonic evolution of the Anaximander Mountains at the junction of the Hellenic and Cyprus arcs. Tectonophysics, 391, p.35-65.

Vougioukalakis G., Ioakim Chr., Economou G., Perissoratis C., Lykousis V., \& Sakellariou D., 2004. A deep sea ash layer (Y2) from the Cape Riva eruption (Santorini volcanic field) at the East Mediterranean submarin Anaximander mountains 2004. $5^{\text {th }}$ International Symposium on Eastern Mediterranean Geology, Greece, Thessaloniki, April 14-20 2004, Proceedings vol 3, p. 1365-1368.

Woodside J. 1996. Neotectonic Deformation of the Anaximander Mountains observed from EM12D multibeam data. In Sedimentary Basins of the Mediterranean and Black Seas. TTR, $4^{\text {th }}$ Post-Cruise Meeting, UNESCO report. p. 11-12.

Woodside, J.M., Mascle, J. \& MEDINAUT shipboard scientific party, 1999. Submersible observations of tectonic control of Eastern Mediterranean mud volcanism and fluid seeps. Journal of Conference Abstracts, EUG 10, 4, 1: 254. 